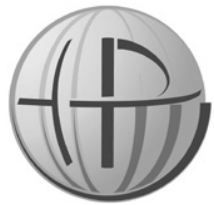

Katarzyna Najbar

http://orcid.org/0000-0002-7088-7044 Uniwersytet Ekonomiczny w Krakowie najbark@uek.krakow.pl

DOI: $10.35765 /$ HP.2133

Horyzonty Polityki

2021, Vol. 12, No 40

OPEN ACCESS

\title{
Świadczenie usług zarządzania nieruchomościami w dobie pandemii COVID-19
}

\section{Streszczenie}

CEL NAUKOWY: Celem artykułu jest ocena wpływu pandemii COVID-19 na obsługę wybranego segmentu rynku nieruchomości oraz na koszty związane z utrzymaniem obiektów.

PROBLEM I METODY BADAWCZE: Kwestionariusz ankiety z pytaniami otwartymi skierowano do wszystkich zarządców nieruchomości zrzeszonych w Instytucie Gospodarki Nieruchomościami, aby ocenić wpływ pandemii COVID-19 na wybrane aspekty rynku nieruchomości. Następnie dokonano zestawienia analitycznego polegającego na analizie danych dla określonego pytania z poszczególnych grup respondentów.

PROCES WYWODU: Pandemia COVID-19 wpłynęła na koszty obsługi nieruchomości, w tym w największym stopniu w obszarze dotyczącym utrzymania czystości. Równolegle zmieniły się oczekiwania właścicieli nieruchomości, w większości na typowe, ujawniające się w okresie kryzysów gospodarczych. Zarządzający nieruchomościami musieli zatem zmierzyć się z nowymi obowiązkami, a ich wynagrodzenie $\mathrm{z}$ tego tytułu nie uległo zmianie. Co ważne, dla takiej sytuacji rynkowej, nie zostało ono również obniżone. Zarządcy nieruchomości w zakresie części obowiązków zaczęli działać online, a ich zespoły zaczęły pracować hybrydowo. Przedsiębiorstwa rozwinęły się technologicznie poprzez zakup bądź zintensyfikowanie wykorzystania oprogramowania i sprzętu. Wdrożono również nowe zasady organizacji pracy, zapewniając wymagane środki bezpieczeństwa. 
WYNIKI ANALIZY NAUKOWEJ: Przeprowadzone badania potwierdzają że pandemia COVID-19 wpłynęła na wzrost kosztów utrzymania nieruchomości. Na skutek zmieniających się oczekiwań właścicieli obiektów oraz koniecznych do wdrożenia zasad bezpieczeństwa dla zarządców nieruchomości rozpoczął się czas intensywnej pracy. Równolegle czas pandemii COVID-19 wpłynął na rozwój technologii informatycznych wykorzystywanych przez zarządzających w swojej pracy oraz na upowszechnienie pracy zdalnej, która częściowo pozostanie obecna w dalszym funkcjonowaniu firm zarządzających.

WNIOSKI, INNOWACJE, REKOMENDACJE: Ten artykuł jest jednym z nielicznych, które zajęły się wpływem pandemii COVID-19 na zmiany w obszarze kosztów utrzymania nieruchomości oraz zakres i sposób realizacji zadań przez zarządców nieruchomości. Warto jednak zauważyć, że nie potwierdzono, w jakim stopniu pandemia COVID-19 miała wpływ na powyższe oraz czy zauważone zmiany będą miały charakter stały. Uzasadnia to konieczność dalszych badań.

\section{SŁOWA KLUCZOWE:}

rynek nieruchomości, zarządzanie nieruchomościami, COVID-19, koszty obsługi nieruchomości

\section{Abstract}

\section{PROVIDING PROPERTY MANAGEMENT SERVICES IN THE TIME OF COVID-19 PANDEMIC}

RESEARCH OBJECTIVE: The objective of the article is to assess the impact of COVID-19 pandemic on a selected segment of real estate services ant the costs related to the maintenance of property

THE RESEARCH PROBLEM AND METHODS: For the purpose of assessing the impact of COVID-19 pandemic on selected aspects of the real estate market a survey questionnaire with open-ended questions was distributed amongst all the property managers associated in the Institute of Real Estate Economy.

THE PROCESS OF ARGUMENTATION: The COVID-19 pandemic had an impact on the costs of real estate servicing, including significantly in the area of maintaining its cleanliness. At the same time, the expectations of real estate owners have changed, mostly to the typical ones, revealed during the period of economic crises. Property managers therefore had to deal with new responsibilities, and their remuneration for this has not changed. Importantly for this market situation, it was also not lowered. Property managers have started online activities for certain responsibilities and their teams have started working as a hybrid. Their companies developed technologically through the purchase or intensification of the use of software and hardware. They also implemented new rules of work organization ensuring the required safety measures. 
Świadczenie usług zarządzania nieruchomościami w dobie pandemii

RESEARCH RESULTS: The conducted research confirms that the COVID-19 pandemic contributed to an increase in the cost of maintaining the property. Due to the changing expectations of the owners of the facilities and the necessary safety rules for property managers, it is a time of intense work. It is worth noting, however, that it was confirmed to what extent the COVID-19 pandemic had an impact on the above and whether the changes would be permanent, therefore the need for further studies.

CONCLUSIONS, INNOVATIONS, AND RECOMMENDATIONS: This article is one of the few that dealt with the impact of the COVID-19 pandemic on property maintenance costs and the scope and manner of performing property managers' tasks at that time.

\section{KeYwORDS:}

property market, property management, COVID-19, real estate servicing costs

\section{WSTĘP}

Jest połowa 2021 roku - mija 1,5 roku życia w pandemii COVID-19. Od kilkunastu miesięcy świat nadal uczy się zarządzać niepewnymi i nieoczekiwanymi zdarzeniami w każdym obszarze życia człowieka. Badania wskazuja że pandemia COVID-19 ma wpływ na wszystkie aspekty funkcjonowania człowieka (Zahra, 2020; Liguori \& Winkler, 2020) i całkowicie zmieniła otoczenie gospodarcze (Kufel, 2020; Korzeb \& Niedziółka, 2020; Ratten, 2020). Rządy wielu krajów podjęły szereg surowych ograniczeń, które wpłynęły nie tylko na funkcjonowanie społeczeństwa, ale także na gospodarki narodowe (Phelan i in. 2020). Natomiast firmy muszą stawić czoła różnorodnym wyzwaniom związanych z wdrożeniem wymaganych środków ochronnych we własnych organizacjach, a także związanych ze zmniejszeniem popytu, zakłóceniami produkcji i łańcucha dostaw (Kraus i in., 2020, Józefowicz i in., 2020).

Dla długoterminowych zmian w zachowaniu konsumentów $i$ inwestorów, w szczególności przy zwiększaniu oszczędności kosztem inwestycji i wydatków konsumpcyjnych, niezmierne ważne jest opracowywanie polityki i procedur minimalizujących wpływ pandemii na dany, wrażliwy sektor. Jednym z nich jest z pewnością rynek nieruchomości, a pojawienie się COVID-19 można rozpatrywać 
w kontekście zmian na tym rynku, w tym na rynku mieszkaniowym (Marona \& Tomal, 2020; Carson i in., 2020; Francke \& Korevaar, 2021) oraz w zakresie jego obsługi (Marona \& Tomal, 2020; Ngoc i in., 2020, Koszel, 2021). Analiza wyników dotychczasowych badań przeprowadzonych $w$ pierwszych miesiącach pandemii COVID-19 potwierdza, że sytuacja na rynku nieruchomości w bardzo krótkim czasie uległa drastycznemu pogorszeniu. Dotyczy to w szczególności agentów nieruchomości oraz rzeczoznawców majątkowych. Jednoznaczna i skrajnie negatywna ocena sytuacji ogólnej i zawodowej na rynku nieruchomości dotyczy modelu pracy opartego na bezpośrednim kontakcie z klientami lub kontrahentami (Koszel, 2021). W tym kontekście autorka docieka, jak pandemia COVID-19 wpłynęła na długoterminową obsługę zróżnicowanych funkcjonalnie obiektów i realizację usług z nimi związanych.

Szczegółowe problemy badawcze zostały sformułowane w poniższych pytaniach:

1. Czy i w jakich obszarach $w$ ostatnich kilkunastu miesiącach zmieniła się obsługa nieruchomości?

2. Czy pandemia COVID-19 miała wpływ na koszty obsługi nieruchomości?

3. Jak podmioty świadczące usługi zarządzania nieruchomościami wdrożyły zmiany w obsłudze klienta/nieruchomości na skutek pandemii COVID-19?

4. Czy pandemia COVID-19 zahamowała rozwój podmiotów zarządzających nieruchomościami?

Niniejszy artykuł stanowi nowy, niezbadany dotychczas aspekt wpływu pandemii COVID-19 na obsługę wybranego segmentu rynku nieruchomości i koszty związane z utrzymaniem obiektów. W artykule wskazano na przegląd badań z zakresu wpływu pandemii COVID-19 na rynek nieruchomości i jego obsługę. Następnie, bardzo istotne dla poszerzenia wiedzy w zakresie obsługi obiektów podczas pandemii COVID-19 są badania przeprowadzone wśród polskich podmiotów zarządzających nieruchomościami, wskazujące na kierunki zmian w zakresie obsługi nieruchomości, jej kosztów oraz sposobu i rozwoju świadczonych usług. Po analizie wyników przeprowadzonych badań wskazano na ich ograniczenia i propozycje przyszłych analiz. 
Świadczenie usług zarządzania nieruchomościami w dobie pandemii

\section{METODY I NARZĘDZIA BADAWCZE}

Celem przeprowadzenia zamierzonego badania pilotażowego przygotowano kwestionariusz ankiety z pytaniami otwartymi, który został opracowany przy użyciu ogólnodostępnego, bezpłatnego narzędzia, a link do niego został rozesłany przez Instytut Gospodarki Nieruchomościami prawie 1500 osobom, które funkcjonują na rynku usług zarządzania nieruchomościami. Były to podmioty, które uzyskały licencję zarządcy nieruchomości tej organizacji.

Kwestionariusz składał się z sześciu pytań, wszystkie o charakterze otwartym. Respondenci mieli odpowiedzieć na trzy pytania dotyczące zauważonych zmian w obszarze kosztów utrzymania nieruchomości, w tym kosztów usługi zarządzania oraz w zakresie zmiany wymagań/oczekiwań ich właścicieli. Odpowiedzi na te pytania miały na celu ujawnienie różnic dotyczących ww. zmian w przypadku nieruchomości mieszkaniowych i komercyjnych oraz potwierdzenie roli zarządzających w kształtowaniu kosztów utrzymania nieruchomości oraz ich wartości (Carswell, 2017; Read \& Carswell, 2018). Jak wspomniano we wstępie, w okresie pandemii COVID-19 nieruchomości mieszkaniowe zostały mocniej eksploatowane przez użytkowników często zmuszonych do pozostania w obiekcie zamieszkania wskutek nałożonych obostrzeń. W związku z tym pojawiła się dodatkowa konieczność sprostania zmieniającym się wymaganiom sanitarnym. Nieruchomości komercyjne opustoszały bądź były używane $w$ niewielkim zakresie, a ich właściciele mimo długoterminowych umów najmu nie generowali dochodów na dotychczasowym poziomie na skutek m.in. renegocjacji tych umów, a w konsekwencji obniżek czynszów, wyprowadzki studentów czy najemców biur i ich pracowników.

Druga część badania nawiązywała do ankiety przeprowadzonej w lipcu 2020 roku (Marona \& Tomal, 2020) celem porównania wyników w zakresie różnic w sposobie realizacji pracy i stosowanych procedur $w$ trakcie pandemii COVID-19 przez dwa zawody rynku nieruchomości - pośredników w obrocie nieruchomościami oraz zarządców nieruchomości. Pytania w ankiecie autorki tekstu zostały skierowane do podmiotów zajmujących się wyłącznie obsługą nieruchomości w zakresie zarządzania, aby m.in. sprawdzić czy informacje na temat niepewnej przyszłości zawodów nieruchomościowych 
(Koszel, 2021) dotyczą zarządzających. Zwłaszcza, że dotychczasowe doświadczenia wskazuja, iż branża usług zarządczych opiera się kryzysowi (Kucharska-Stasiak, 2006), gdyż w trakcie złej koniunktury gospodarczej jest na nią największe zapotrzebowanie (Burgering, 2008). Warto podkreślić, że dotychczasowe badania dotyczyły m.in. kryzysu finansowego, a kryzys związany z COVID-19 jest innego rodzaju, bez ustalonej daty rozpoczęcia i zakończenia (Ratten, 2020).

Ankieta została tak skonstruowana, że jej wyniki miały być również próbą odpowiedzi na pytanie, czy w związku ze zwiększonym zaangażowaniem podmiotów zarządzających w utrzymanie obiektów i równoczesną presją na ograniczenie kosztów utrzymania nieruchomości, podmioty te mogły liczyć na zwiększoną gratyfikację (Węgrzyn \& Najbar, 2020) oraz czy zależna ona była od rodzaju nieruchomości czy również innych czynników. I ostatnia sprawa, czy pandemia COVID-19 przyczyniła się w Polsce do niesłabnącego od wielu lat rozwoju usług zarządczych (Najbar, 2013; Najbar \& Węgrzyn, 2018).

Pytania te miały na celu ujawnienie opinii respondentów na temat zmian $\mathrm{w}$ organizacji pracy podmiotów zarządzających nieruchomościami pod wpływem pandemii COVID-19 oraz ustalenie, czy wprowadzone w tym zakresie zmiany mogą być trwałe i utrzymać się również po zakończeniu pandemii.

Kwestionariusz ankiety był dostępny od 25 maja do 13 czerwca 2021 roku. Adresaci byli dwukrotnie zapraszani do jej wypełnienia. Ostatecznie udało się pozyskać 41 wypełnionych ankiet, w zasadzie wyłącznie od zarządców nieruchomości z doświadczeniem zawodowym powyżej 10 lat (ponad 95\% respondentów). Respondenci w swoim portfolio posiadali w przeważającym stopniu nieruchomości mieszkaniowe. Dokładne dane dotyczące osób biorących udział w badaniu zawarte są $\mathrm{w}$ tabeli 1 .

Pomimo niskiego odsetka odpowiedzi (2,73\%) badanie można uznać za wiarygodne. Badania ankietowe wśród przedsiębiorców charakteryzują się znacznie mniejszą liczbą odpowiedzi w porównaniu z innymi rodzajami respondentów, takimi jak np. gminy. Ponadto analiza przeprowadzona przez Holbrook i in. (2008) udowadnia, że ankiety o niskim wskaźniku odpowiedzi są nieznacznie mniej dokładne niż te o wysokim wskaźniku odpowiedzi.

Jednocześnie należy zauważyć, że ankieta została skierowana do osób, które posiadają licencję, lecz nie wszystkie z nich czynnie 
Świadczenie usług zarządzania nieruchomościami w dobie pandemii

uprawiają ten zawód i należy założyć, że ankietę wypełnili tylko ci, którzy są aktywni zawodowo. Ponadto ankieta miała charakter pytań otwartych, a te wyjątkowo zniechęcają respondentów do udzielenia odpowiedzi. Jednak uzyskanie 41 ankiet w pełni wypełnionych przez doświadczone podmioty zarządzające nieruchomościami ma niewątpliwie charakter ekspercki.

Tabela 1. Charakterystyka grupy respondentów (metryczka)

\begin{tabular}{|l|l|c|}
\hline \multirow{2}{*}{ Zmienna } & Wartości zmienne & $\begin{array}{c}\text { Odsetek } \\
\text { odpowiedzi } \\
\text { w próbie (\%) }\end{array}$ \\
\hline \multirow{2}{*}{ Płeć } & Kobieta & $43,9 \%$ \\
\cline { 2 - 3 } & Mężczyzna & $56,1 \%$ \\
\hline \multirow{4}{*}{ Doświadczenie } & Do 5 lat & $0 \%$ \\
\cline { 2 - 3 } & Od 5 do 10 & $4,9 \%$ \\
\cline { 2 - 3 } & Powyżej 10 & $95,1 \%$ \\
\hline \multirow{2}{*}{$\begin{array}{l}\text { Przeważający rodzaj nieruchomości będący } \\
\text { przedmiotem zarządzania w firmie }\end{array}$} & Mieszkalne & $80,5 \%$ \\
\cline { 2 - 3 } & Niemieszkalne & $19,5 \%$ \\
\hline
\end{tabular}

Źródło: badania własne.

\section{USŁUGI ZARZĄDZANIA NIERUCHOMOŚCIAMI W OKRESIE PANDEMII COVID-19}

Rynkowe usługi świadczone na rzecz uczestników rynku nieruchomości rozwijają się na polskim rynku od ponad trzech dekad. W wielu obszarach intensywny rozwój nastąpił dzięki adaptacji rozwiązań z rynków zagranicznych. Trzy zawody, wprowadzone ustawą z dnia 21 sierpnia 1997 roku o gospodarce nieruchomościami, przez prawie 25 lat funkcjonowania na polskim rynku wypracowały zasady ich funkcjonowania, organizacji czy też licencjonowania. Prowadzone przez te podmioty usługi pośrednictwa w obrocie nieruchomościami, rzeczoznawstwa majątkowego oraz zarządzania nieruchomościami wykształciły w tym czasie sprawdzone struktury organizacyjne, specjalizacje, procedury postępowania oraz sposoby komunikacji. Pandemia COVID-19 odcisnęła swoje piętno na każdym z tych typów usług (Marona \& Tomal, 2020; Źróbek \& Kucharska-Stasiak \& Reiniger-Biłozor, 2020; Koszel, 2021). Firmy ograniczyły swoją działalności, inne ją zdywersyfikowały lub wykorzystały sytuację 
niepewności do niespodziewanego rozwoju. Równolegle musiały dostosować się do nowych reguł postępowania i zachowania bezpieczeństwa we własnych firmach (chroniąc swoich pracowników) oraz próbować przystosowywać świadczone usługi do zmieniających się realiów na rynku nieruchomości. Nagła konieczność wdrożenia zarządzania kryzysowego na obu poziomach (wewnątrz firm oraz $\mathrm{w}$ relacji z klientami i kontrahentami) zapoczątkowała etap zarządzania nieznanym i nieoczekiwanym.

Poniżej autorka przechodzi do przedstawienia uzyskanych wyników na sześć postawionych w badaniu pytań.

\section{ZMIANA ZACHOWAŃ NA RYNKU NIERUCHOMOŚCI}

Duży wpływ na zachowania na rynku nieruchomości miała zmiana lokalizacyjna aktywności życiowych. W wyniku pandemii COVID-19, na skutek wprowadzanych i zmienianych ograniczeń oraz restrykcji, pracownicy opuścili w dużej mierze swoje dotychczasowe miejsca pracy rozumiane jako lokalizacje/powierzchnie i przenieśli swoją aktywność zawodową do mieszkań i domów. Podobnie sytuacja wyglądała z uczącymi się dziećmi i studentami. Lockdown w wielu krajach spowodował rozwój pracy zdalnej i nauki zdalnej (Gruenwald, 2021). Ta przeciągająca się w czasie sytuacja wpłynęła na to, że pewne rodzaje obiektów (nieruchomości mieszkaniowe) zaczęły się „przepełniać” i z tego powodu wymagać większej uwagi niż nieruchomości, w których do tej pory była zlokalizowana praca i nauka. Po drugiej stronie pojawiła się konieczność sprostania nowym problemom wynikającym z rosnącej liczby pustoszejących obiektów komercyjnych (biurowych, handlowych, hotelowych) oraz obiektów użyteczności publicznej (szkół, przedszkoli, instytucji i urzędów). I mimo iż sytuacje wzmożonego bądź zmniejszonego obłożenia/zajętości obiektów komercyjnych były już wcześniej doświadczane, to do tej pory nie miało to miejsca w taki nagły sposób (w tak nieprzewidywalnym zakresie czasowym i powierzchniowym), z jednoczesnym dociążeniem nieruchomości mieszkaniowych wykorzystywanych przez właścicieli na własne potrzeby. 


\section{ZMIANA OCZEKIWAŃ WŁAŚCICIELI NIERUCHOMOŚCI}

W sytuacji kryzysu gospodarczego właściciele nieruchomości weryfikują swoje cele z nimi związane i należą do nich przede wszystkim:

- utrzymywanie bądź obniżenie kosztów utrzymania nieruchomości przy jednoczesnym utrzymaniu jakości obsługi nieruchomości;

- utrzymanie wartości nieruchomości;

- utrzymanie dotychczasowych najemców;

- dywersyfikacja użytkowania nieruchomości, by zapewnić dochodowość nieruchomości na niezmienionym poziomie (Najbar, 2012).

Większość z powyższych celów pojawiła się również wraz z pandemią COVID-19. Wystąpiły również czynniki różnicujące kryzys gospodarczy od pandemii COVID-19, w tym głównie obostrzenia sanitarne, ograniczenia przemieszczania się, z którymi świat nie miał dotychczas do czynienia.

Na pytanie dotyczące zmiany oczekiwań właścicieli nieruchomości, co do usługi świadczonej przez firmy zarządzające w związku z pandemią COVID-19, aż 75\% respondentów reprezentujących nieruchomości komercyjne potwierdziło, że zmieniły się oczekiwania ich właścicieli w stosunku do zarządców tych nieruchomości i sposobu świadczonej przez nich usługi. Respondenci ci wskazali na obszary nowych wyzwań, do których zaliczyli:

- opracowywanie nowych procedur bezpieczeństwa;

- poszukiwanie alternatywnych przychodów wobec obniżających się wpływów z czynszów;

- poszukiwanie oszczędności.

Zmianę podejścia właścicieli nieruchomości do sposobu świadczenia usług przez zarządców nieruchomości potwierdziło 59\% respondentów i jednocześnie ponad $1 / 3$ ankietowanych nie zauważyła żadnych zmian, a 5\% nie miało w tym zakresie swojego zdania. Firmy, które odnotowały zmiany we wzajemnych relacjach, wskazały na najbardziej kluczowe obszary, do których należały:

- kontrola utrzymania czystości;

- nadzór nad dezynfekcją powierzchni zgodnie z wytycznymi i zaleceniami; 
- bieżące raportowanie na temat działań wdrożonych na nieruchomości.

Część respondentów zauważyła, że wzrosła im ilość obowiązków, wymagany był wzrost jakości pracy (w tym obsługa online).

Jak wskazano powyżej, nieruchomości mieszkaniowe zostały obciążone $\mathrm{w}$ dużo większym zakresie niż w normalnych warunkach, w przeciwieństwie do nieruchomości biurowych, handlowych, turystycznych i użyteczności publicznej, gdzie nastąpił chwilowy odpływ dotychczasowych użytkowników. W związku z tym zauważono pewne działania wspólne wykonywane przez zarządzających dla wszystkich rodzajów nieruchomości oraz czynności, które wykonywane były wyłącznie dla niektórych z nich.

Wśród działań podjętych przez wszystkie podmioty zarządzające w trakcie pandemii COVID-19 należy wymienić:

- dbałość o spełnienie wymogów sanitarnych dotyczące utrzymania nieruchomości (w tym dezynfekcji) celem zapewnienia nierozprzestrzeniania się wirusa;

- bieżące wdrażanie zaleceń związanych z obostrzeniami w przemieszczaniu się, norm dotyczących liczby osób dopuszczalnych na daną powierzchnię, możliwości korzystania z części wspólnych, w tym rekreacyjnych;

- zapewnienie bezpieczeństwa przebywania użytkowników w nieruchomościach, w tym sprawdzanie pracy instalacji i urządzeń (Lapin, 2021);

- dbałość o regularne wpłaty użytkowników nieruchomości;

- próba sprostania utrudnionemu w okresie pandemii COVID-19 nadzorowi nad firmami świadczącymi bieżące usługi dla nieruchomości, a około połowa firm zarządzających korzysta w obszarach utrzymania czystości oraz obsługi technicznej z zewnętrznych dostawców (Najbar \& Węgrzyn, 2018);

- rozpoznanie pomocy rządowej, lokalnej oferowanej użytkownikom nieruchomości (tzw. tarcze antykryzysowe, brak eksmisji (JPM, 2020), niewykonywanie egzekucji z lokali);

- dostosowanie swojej pracy do wymogów pracy zdalnej (pomimo iż normalnie znaczną część czasu pracy zarządzający spędzają wizytując nieruchomości);

- ograniczenie obsługi bezpośredniej do minimum wraz z wprowadzeniem pośrednich metod kontaktu i komunikacji. 
Świadczenie usług zarządzania nieruchomościami w dobie pandemii

W przypadku nieruchomości komercyjnych dodatkowo należy wskazać na następujące działania podejmowane przez zarządzających:

- renegocjacje umów najmu, w tym często obniżenie wysokości czynszu wraz z wydłużeniem czasu trwania umowy najmu (ok. 70\% najemców nieruchomości biurowych zgłosiło się do wynajmujących z prośbą o obniżenie wysokości czynszu) (Salustri, 2020));

- ugody z najemcami;

- utrzymywanie płynności finansowej nieruchomości (balans pomiędzy wpływami a kosztami obsługi nieruchomości oraz kosztami ewentualnego zadłużenia);

- próby ograniczenia kosztów utrzymania nieruchomości;

- zabezpieczenie (ochrona) opustoszałych powierzchni (Salustri, 2020);

- zapewnienie środków do dezynfekcji na powierzchniach wspólnych, stacji monitorujących temperaturę ciała osób wchodzących do obiektów.

W przypadku nieruchomości mieszkaniowych do nowych zadań zarządców w okresie pandemii COVID-19 należy:

- instruowanie osób chorych na COVID-19 lub przebywających na kwarantannie celem zapewnienia bezpieczeństwa pozostałym mieszkańcom;

- nadzór nad czasowym przesunięciem obowiązkowych przeglądów technicznych wykonywanych w lokalach (na mocy decyzji Głównego Urzędu Nadzoru Budowlanego zezwalającej na wypełnienie tego obowiązku w późniejszym czasie);

- dbałość o regularne wpłaty opłat na media z uwagi na znaczny wzrost zużycia mediów w lokalach mieszkalnych;

- zapewnienie/weryfikacja odpowiedniej ilości zamówionych mediów, wywozu nieczystości;

- weryfikacja przyjętych budżetów na skutek nieprzewidzianych wydatków.

We wszystkich rodzajach nieruchomości zauważalny był problem realizacji zaplanowanych prac remontowych, przeglądów technicznych, inwestycji. Wszystkich, zarówno użytkowników lokali, jak i pracowników firm wykonawczych, dotykały absencje wynikające z zachorowania na COVID-19 lub objęcia kwarantanna/izolacją. 
Przesuwało to terminy realizacji zadań, które również z tego powodu zaczęły się piętrzyć.

\section{KOSZTY UTRZYMANIA NIERUCHOMOŚCI}

Dla niemalże 83\% badanych respondentów pandemia COVID-19 miała bezpośredni wpływ na wzrost kosztów utrzymania nieruchomości. Wskazali oni na następujące obszary wzrostu kosztów:

- utrzymanie czystości i dezynfekcja (94\% wskazań);

- utrzymanie techniczne, w tym konserwacja bieżąca, przeglądy techniczne, materiały do konserwacji (35\%);

- zarządzanie nieruchomością (9\%);

- organizacja pracy zdalnej (9\%);

- ochrona fizyczna (3\%).

Wśród wymienionych kosztów wyraźnie dominuje wzrost kosztów usługi związanej z utrzymaniem czystości i dezynfekcją. Istotny jest fakt, iż część respondentów zasygnalizowała inne czynniki, które wpłynęły na wzrost kosztów obsługi nieruchomości w Polsce, tj. zmiana wysokości wynagrodzeń, od kilku lat coroczny wzrost płacy minimalnej oraz dotkliwy brak pracowników we wszystkich wskazanych powyżej branżach (utrzymanie czystości, utrzymanie techniczne, ochrona fizyczna). Warto zauważyć, że te dodatkowo wymienione czynniki mogły nie mieć wpływu na koszt obsługi nieruchomości w innych krajach, gdyż mogły tam równolegle nie wystąpić.

Prawie 17\% respondentów nie powiązało pandemii COVID-19 ze wzrostem kosztów utrzymania obiektów. Wśród nich dominowali zarządcy nieruchomości komercyjnych, stanowiąc ponad $70 \%$ odpowiedzi w tej grupie. Można to tłumaczyć m.in. próbami ograniczenia kosztów utrzymania nieruchomości, w tym usług sprzątania, z tym że większość z nich była kontraktowana od powierzchni, a nie od liczby użytkowników czy zajętości obiektów (Salustri, 2020). W sytuacji, gdy udało się renegocjować koszty utrzymania, to jednak dodatkowe koszty dezynfekcji je równoważyły. 


\section{KOSZTY USŁUGI ZARZĄDZANIA NIERUCHOMOŚCIAZ}

Na pytanie dotyczące wpływu pandemii COVID-19 na wysokość stawek za usługi zarządzania żaden respondent nie wskazał, że wynagrodzenia za te usługi się zmniejszyły. Ponad 2/3 respondentów nie doświadczyło zmian w tym zakresie (w tym prawie $90 \%$ zarządców nieruchomości komercyjnych). W przypadku tych ostatnich pandemia COVID-19 nie miała wpływu na zmianę wynagrodzenia zarządzających. Co ciekawe prawie $1 / 3$ zarządców odnotowała wzrost swojego wynagrodzenia na skutek wystąpienia pandemii COVID-19, w tym:

- $38 \%$ wzrost do $5 \%$ w stosunku do okresu sprzed pandemii COVID-19;

- $31 \%$ wzrost w przedziale $5-10 \%$;

- $31 \%$ wzrost powyżej $10 \%$

O ile tylko 1/3 zarządców wskazała pandemię COVID-19 jako podstawowy/wiodący czynnik wzrostu wynagrodzeń zarządców, to łącznie o wzroście ceny usługi zarządzania opowiedziało się niemal $44 \%$ respondentów. Dodatkowo wskazali oni następujące czynniki będące przyczyną wzrostu ich wynagrodzenia:

- inflacja,

- rosnące koszty pracy,

- wzrost cen mediów,

- mniejsza podaż usług na tym rynku.

Brak obniżenia wynagrodzenia w okresie pandemii COVID-19, a w pewnej części odnotowany jego wzrost należy ocenić bardzo pozytywnie.

\section{ZMIANA ORGANIZACJI PRACY}

\section{ZARZĄDZAJĄCYCH}

Praca zarządzających nieruchomościami to praca zespołowa realizowana na rzecz właścicieli nieruchomości. Od dłuższego już czasu w znaczącej części wykonywana z wyłączeniem bezpośredniego kontaktu z klientem i kontrahentami obsługującymi nieruchomość. Praca zarządzających organizowana w biurze to niewątpliwie te 
zadania, które związane są z obsługą księgowa obsługą korespondencji, przygotowaniem dokumentacji, tj. umowy, zaświadczenia, rozliczenia kosztów. W dużej części zarządzający nadzorują prace innych serwisów prowadzonych w nieruchomościach, odwiedzając je bezpośrednio, często bez udziału innych osób. Odbywa się to na zasadzie kontroli wykonanych usług na rzecz nieruchomości. Nawet przedmiary prac, będących przedmiotem ofertowania przez zewnętrzne podmioty, odbywają się coraz częściej bez bezpośredniego kontaktu, np. dzięki technologii Cloud - BIM (Małkowska, 2020). W przypadku nieruchomości mieszkaniowych bieżące udzielanie informacji właścicielom nieruchomości już od dłuższego czasu jest realizowane przez telefon, e-mail oraz platformy do wymiany informacji (internetowe kartoteki mieszkańców).

Wśród respondentów jedynie $7 \%$ wskazało, że podczas pandemii COVID-19 praca biur nie zmieniła się i dotyczyło to wyłącznie zarządców nieruchomości komercyjnych. Równocześnie po drugiej stronie byli respondenci, którzy doświadczyli całkowitego zamknięcia biur i wyłącznej obsługi online. Stanowili oni prawie $22 \%$ ankietowanych respondentów. Duża część zarządzających (ponad $40 \%$ ) wskazywała na pracę rotacyjną w biurze (zmiany pracowników pełniących dyżur). W ich biurach dopuszczono możliwość pracy hybrydowej (łączenie pracy zdalnej ze stacjonarną). Część respondentów podzieliła się praktycznymi rozwiązaniami wdrożonymi $\mathrm{w}$ tym czasie w biurach, np. w sposobie rozlokowania pracowników w pokojach, zakupie i montażu przysłon, ustaleniu liczby osób do kontaktu z klientami. Zarządcy zwrócili również uwagę na poniesione koszty tych dostosowań. Dodatkowo, aby sprostać pracy zdalnej, wiele podmiotów wydatkowało środki na sprzęt komputerowy, systemy zabezpieczeń oraz oprogramowanie do pracy i spotkań online. Zastosowanie pracy zdalnej okazało się rozwiązaniem, które pozytywnie wpłynęło na funkcjonowanie przedsiębiorstw (Józefowicz \& Smolińska \& Wiza, 2020).

Na pytanie, czy zmiany w pracy biura wprowadzone podczas pandemii COVID-19 będą miały charakter trwały zdania były podzielone. Spośród ponad 40\% wszystkich respondentów, którzy wprowadzili zmiany w pracy swoich biur, prawie połowa twierdzi, że zmiany te nie będą miały trwałego charakteru, bo praca ta wymaga obecności zarządzającego w budynkach oraz wizji, której nie można 
Świadczenie usług zarządzania nieruchomościami w dobie pandemii

wykonać zdalnie. Druga, większa część tych, którzy wdrożyli zmiany uznała, że utrzyma pracę zdalną po pandemii COVID-19 w całości lub w części.

\section{ROZWÓJ FIRM ZARZĄDZAJĄCYCH NIERUCHOMOŚCIAMI}

Prawie połowa respondentów (ponad 46\%) pozytywie ocenia wpływ dotychczasowego okresu pandemii COVID-19 na rozwój firmy zarządzającej. Wśród czynników, które miały wpływ na rozwój organizacji oraz kompetencji zespołu respondenci, wskazali:

- zakup i rozwój oprogramowania wspierającego pracę zdalną i spotkania online;

- zmiany w systemie pracy;

- nowe zdalne rozwiązania dotyczące przepływu informacji i dokumentów;

- wdrożenie nowych technologii do monitoringu nieruchomości;

- dodatkowe zlecenia, nowe kontrakty/projekty.

Za odczuwalnym rozwojem firmy opowiedziały się te podmioty, które musiały sprostać zwiększonym wymaganiom właścicieli nieruchomości. Dotyczyło to ponad połowy ww. respondentów. Pozostała część z nich uznała, że dobra passa jest wynikiem działań przeprowadzonych wewnątrz firmy, gdyż w tym samym czasie nie odnotowały nowych oczekiwań właścicieli.

Co szósty ankietowany nie zauważył zmian w rozwoju swojej firmy bądź nie miał zdania w tym temacie, często wskazując na zbyt krótki czas trwania pandemii COVID-19 do dokonania oceny.

Jednocześnie $36 \%$ ankietowanych respondentów potwierdziło, że ich firma się nie rozwinęła. Jako przyczyny takiego stanu rzeczy wskazywano na zwiększony zakres obowiązków w okresie pandemii COVID-19 i w związku z tym brak czasu na dokonywanie świadomych działań prorozwojowych, brak możliwości bezpośrednich spotkań z klientami oraz brak spotkań zespołu. 


\section{WYNIKI}

Wyniki badań pilotażowych jednoznacznie wskazują że w trakcie pandemii COVID-19 branża zarządzania nieruchomościami zachowała stabilną pozycję wewnątrz organizacji oraz na rynku usług wspomagających rynek nieruchomości. Mimo ogromnych wahań na rynku najmu nieruchomości komercyjnych i w konsekwencji nowych wyzwań dla zarządzających, podmioty te przyjęły tę sytuację pozytywnie i oceniły, że wpływa ona na rozwój tych firm (nawet za cenę zamrożenia wzrostu wysokości ich wynagrodzeń). Uwarunkowania na rynku usług zarządzania nieruchomościami mieszkaniowymi były odmienne, ale także w konsekwencji przyczyniły się w dużej części do rozwoju tych podmiotów lub co najmniej do zachowania ich status quo. Wzrost liczby osób przebywających w budynkach mieszkalnych oraz zmieniające się wymagania sanitarne mobilizowały zarządzających do sprostania nowym oczekiwaniom w zakresie bezpieczeństwa sanitarnego użytkowania obiektów mieszkalnych, w których przebywali zarówno zdrowi mieszkańcy, jak i ci, którzy znajdowali się na kwarantannie lub w izolacji.

Wśród zarządzających ujawniła się duża grupa podmiotów uznających, że podstawą efektywnego zarządzania są wizje w nieruchomościach, praca stacjonarna $\mathrm{w}$ biurze i bezpośrednie spotkania z użytkownikami obiektów i kontrahentami. Części argumentom trudno zaprzeczyć, gdyż nadzoru nad kontrahentami czy sprawdzanie postępu wykonywanych prac na nieruchomości trudno dokonać online. I o ile sposób wykonywania pracy przez zarządzających w obiektach pozostanie bez zmian, to nowe rozwiązania dotyczące pracy hybrydowej zespołów zarządzających zostaną w tych organizacjach na dłużej. Trudno w tym miejscu o dogłębną analizę, które podmioty są za utrzymaniem rozwiązań wdrożonych $w$ trakcie pandemii COVID-19. Czy są to firmy, które potwierdziły równolegle rozwój organizacji, czy te, które tego rozwoju nie odnotowały?

Na podstawie wyników badań można ostrożnie wysnuć wnioski, iż podmioty zarządzające uważają, że w badanym okresie dotknęła ich pewna stagnacja. Miało to według nich miejsce na skutek spowolnienia realizacji swoich obowiązków czy braku dotychczasowych kontaktów bezpośrednich (m.in. brak zebrań członków wspólnot mieszkaniowych). Warto zauważyć, że w konsekwencji żaden 
Świadczenie usług zarządzania nieruchomościami w dobie pandemii

z ww. respondentów nie zaliczył do skutków braku rozwoju firmy utraty swoich klientów poprzez wypowiedzenia dotychczasowych umów czy też kontraktów.

W zakresie kosztów utrzymania nieruchomości w badanym okresie warto podkreślić, że pandemia COVID-19 w Polsce towarzyszyła równolegle innym zmianom w gospodarce (wzrostowi wynagrodzeń oraz rosnącym kosztom świadczonych usług i mediów). Dlatego trudno jednoznacznie określić, w jakim stopniu pandemia COVID-19 przyczyniła się do podwyższenia kosztów utrzymania budynków. Są jednak pewne wydatki, na których wzrost wpłynęła ona bezspornie. Dotyczy to grupy kosztów związanych z zapewnieniem bezpieczeństwa użytkowania nieruchomości w związku z wprowadzonymi zaleceniami.

\section{WNIOSKI I REKOMENDACJE}

Podsumowując powyższe rozważania, można wnioskować, że pandemia COVID-19 w dużej mierze posiada cechy kryzysów gospodarczych oraz kryzysów na rynku nieruchomości, z którymi zarządzający nieruchomościami mieli już do czynienia. Jest to czas, w którym zmieniają się dotychczasowe oczekiwania właścicieli, a zarządzający muszą im sprostać, tym razem jednak szybciej w związku z nieprzewidywalnymi oraz natychmiastowo wprowadzanymi restrykcjami oraz zmianami zachowania użytkowników nieruchomości.

Badania pozwoliły na zrealizowanie nakreślonego celu i odpowiedzi na zadane pytania badawcze. Prawdziwe jest stwierdzenie, że pandemia COVID-19 wpłynęła na koszty obsługi nieruchomości, w tym znacząco w obszarze dotyczącym utrzymania jej czystości. Równolegle zmieniły się oczekiwania właścicieli nieruchomości, w większości na typowe, ujawniające się w okresie kryzysów gospodarczych. Tym samym zarządzający nieruchomościami musieli zmierzyć się z nowymi obowiązkami, a ich wynagrodzenie $\mathrm{z}$ tego tytułu nie uległo zmianie. Co ważne dla tej sytuacji rynkowej, nie zostało ono również obniżone. Zarządcy nieruchomości w zakresie pewnych obowiązków w coraz większym stopniu podjęli pracę zdalnie. Rozwinęli się technologicznie poprzez zakup bądź zintensyfikowanie wykorzystania oprogramowania oraz sprzętu w swoich 
przedsiębiorstwach. Wdrożyli również nowe zasady organizacji pracy, zapewniając wymagane środki bezpieczeństwa oraz pracując hybrydowo.

Przedstawiając jednak powyższe wnioski, należy mieć świadomość, że badanie ma pewne ograniczenia, które jednocześnie stanowią warunek wstępny do podjęcia kolejnych badań w przyszłości. Jak już wspomniano, zawarte w ankiecie pytania otwarte służyły wyłącznie realizacji celu badawczego. Pozwoliło to na uzyskanie korzyści typowych dla analiz jakościowych, tj. przedstawienie dokładniejszego obrazu rzeczywistości, zwłaszcza w sytuacji, gdy nie została ona jeszcze zbadana, co niewątpliwie miało miejsce w przypadku pojawienia się pandemii COVID-19. Pomimo faktu, iż badania nie są reprezentatywne $w$ tej grupie badawczej, to mogą stanowić dane wyjściowe dla przyszłych analiz ilościowych. Zwłaszcza, że kryzys wynikający z pandemii COVID-19 wciąż trwa i istnieje duża niepewność co do przyszłych warunków gospodarczych i społecznych. Poszerzenie badań o zarządców nieruchomości niezrzeszonych w organizacjach zawodowych, głównie działających na rynku nieruchomości komercyjnych, pozwoliłoby zrozumieć, w jaki sposób dostosowano nieruchomości w wyniku panującej pandemii COVID-19. Ponadto, warto by rozważyć rozszerzenie analiz o zagraniczne rynki usług obsługi nieruchomości, by odseparować od dotychczasowych analiz wpływ zmian, które miały miejsce wyłącznie w polskiej gospodarce. Te pozwoliłyby również na wskazanie jak przedsiębiorcy radzą sobie w czasie kryzysu.

\section{BIBLIOGRAFIA}

Burgering, F.A.J. (2008). Przekrój działania zawodów w Unii Europejskiej. Materiały konferencyjne "Zawody nieruchomościowe w krajach Unii Europejskiej i Stanach Zjednoczonych". Warszawa: Polska Federacja Rynku Nieruchomości.

Carson, S. i in. (2021). Imagining a Post-Covid-19 World of Real Estate. Town Planning Review, 92 (3), 371-376. https://doi.org/10.3828/ tpr.2020.63

Carswell, A. (2017). An analysis of operating expense control within US multifamily properties. Property management, 35 (1), 48-66. https:// doi.org/10.1108/PM-10-2015-0053 
Świadczenie usług zarządzania nieruchomościami w dobie pandemii

Franckie, M., \& Korevaar, M. (2021, 25 stycznia). Housing Markets in a Pandemic: Evidence from Historical Outbreaks. SSRN Electronic Journal, 1-54. https://doi.org/10.2139/ssrn.3566909

Gruenwald, H. (2021). Covid-19 and Leisure Real-Estate. https://www. researchgate.net/project/Corona-Collateral-Damage, DOI: 10.13140/ RG.2.2.27126.32328.

Holbrook, A.L., Krosnick, J.A., Pfent, A. (2008). The causes and consequences of response rates in surveys by the news media and government contractor survey research firms. W J.M. Lepkowski, C. Tucker, J.M. Brick, E.D. de Leeuw, L. Japec, P.J. Lavrakas, M.W. Link, R.L. Sangster, (Red.), Advances in Telephone Survey Methodology. https:// doi.org/10.1002/9780470173404.ch23

Journal of Property Management (2020). A Legislative Update, Nov-Dec. https://jpmonline.org/wp-content/uploads/2020/11/JPM-Nov-Dec20-View_Final.pdf

Józefowicz, K. i in. (2020). Działania na rzecz pracowników w czasie pandemii - przykłady wybranych przedsiębiorstw. Intercathedra, 2(43), 73-80. http://dx.doi.org/10.17306/J.INTERCATHEDRA.2020.00099

Korzeb, Z., \& Niedziółka, P. (2020). Resistance of commercial banks to the crisis caused by the COVID-19 pandemic: the case of Poland. Equilibrium. Quarterly Journal of Economics and EconomicPolicy, 15(2), 205-234. https://doi.org/10.24136/eq.2020.010

Koszel, M. (2021). The COVID-19 Pandemic and the Professional Situation on the Real Estate Market in Poland. Conference: Hradec Economic Days 2021. Conference Paper. DOI: 10.36689/uhk/hed/2021-01-042.

Kraus, S. i in. (2020). The economics of Covid-19: initial empirical evidence on how family firms in five European countries cope with the corona crisis. International Journal of Entrepreneurial Behavior $\mathcal{E}$ Research, 26(5), 1067-1092. https://doi.org/10.1108/IJEBR-04-2020-0214

Kucharska-Stasiak, E., (2006). Nieruchomość w gospodarce rynkowe. Warszawa: PWN.

Kufel, T. (2020). ARIMA-based forecasting of the dynamics of confirmed Covid-19 cases for selected European countries. Equilibrium. Quarterly Journal of Economics and Economic Policy, 15(2), 181-204. https://doi. org/10.24136/eq.2020.009

Lapin, J.S. (2021), Come on back, the air is fine!. Journal of Property Management. Institute of Real Estate Management, Jan-Feb, 24-27. https:// jpmonline.org/wp-content/uploads/2020/12/JPM-Jan-Feb21-Final_ view.pdf

Liguori, E., \& Winkler, C. (2020). From Offline to Online: Challenges and Opportunities for Entrepreneurship Education Following the 
COVID-19 Pandemic. Entrepreneurship Education and Pedagogy, 3(4), 346-351. https://doi.org/10.1177/2515127420916738

Małkowska, A. (2020). How Technology Impact the Real Estate Business - Comparative Analysis of European Union Countries. World of Real Estate Journal, 112(2), 58-81. DOI: https://doi.org/10.14659/ WOREJ.2020.112.04.

Marona, B., \& Tomal, M. (2020). The COVID-19 pandemic impact upon housing brokers' workflow and their clients' attitude: Real estate market in Krakow. Entrepreneurial Business and Economics Review, 8(4), 221-232. https://doi.org/10.15678/EBER.2020.080412

Najbar, K., Węgrzyn, J. (2018). The Characteristics of the Institutionalisation of Real Estate Management Services in Poland. Świat Nieruchomości, 106(4), 37-44. DOI: 10.14659/WOREJ.2018.106.005.

Najbar, K. (2012). Rynek usług zarządzania nieruchomościami w dobie kryzysu gospodarczego. Studia i Materiały Towarzystwa Naukowego Nieruchomości, 20 (4), 235-243, http://tnn.org.pl/tnn/publik/20/ TNN_tom_XX_4.pdf

Najbar, K. (2013). Rynek ustug zarzadzania nieruchomościami. Warszawa: Poltext.

Ngoc, N.M. i in. (2020). Opportunities and challenges for real estate brokers in post Covid-19 period. International Journal of Multidisciplinary Research and Growth Evaluation, 1(5). https://www.researchgate.net/ publication/348509773_Opportunities_and_challenges_for_real_estate_brokers_in_post_Covid-19_period

Phelan, A.L. i in. (2020). The novel coronavirus originating in Wuhan, China: challenges for global health governance. Jama, 323(8), 709-710. https://doi.org/10.1001/jama.2020.1097

Ratten, V. (2020). Coronavirus (covid-19) and entrepreneurship: changing life and work landscape. Journal of Small Business E Entrepreneurship, 32(5), 503-516. https://doi.org/10.1080/08276331.2020.1790167

Read, D.C., Carswell, A. (2018). Is property management viewed as a value-added service?, Property Management, 37 (2), 262-274. https://doi. org/10.1108/PM-05-2018-0034

Salustri, J. (2020). Managing the unexpected. Journal of Property Management. Institute of Real Estate Management, July-Aug., 16-25. https:// jpmonline.org/wp-content/uploads/2020/07/JPM-Jul-Aug20-Final-Web-VIEW-1.pdf

Węgrzyn, J., Najbar, K. (2020). Diversification of property managers' fees and their determinants - the case of Poland, Real Estate Management and Valuation, 28(1), 41-50. DOI:10.2478/remav-2020-0004. 
Świadczenie usług zarządzania nieruchomościami w dobie pandemii

Zahra, S.A. (2020). International entrepreneurship in the post Covid world. Journal of World Business, 56(1), 101143. https://doi.org/10.1016/j. jwb.2020.101143

Źróbek, S. i in. (2020). Today`s market needs modernized property appraisers. Real Estate Management and Valuation, 28(4), 93-103. DOI: https://doi.org/10.1515/remav-2020-0034

Publikacja została sfinansowana ze środków subwencji przyznanej Uniwersytetowi Ekonomicznemu w Krakowie.

\section{Copyright and License}

This article is published under the terms of the Creative Commons Attribution - NoDerivs (CC BY- ND 4.0) License http://creativecommons.org/licenses/by-nd/4.0/ 